\title{
Autonomia e Independência da ANATEL no Contexto Juspolítico Brasileiro
}

Vanessa Copeti Cravot

I İntrodução. 2 ANÁTEL e a Concepção de Agência Reguladora. 2.1 A Reforma do Estado e a Criação da ANATEL 2.2 A ANATEL e o Modelo Regulatónio. 3 Os Atributos de Autonomia e lndependência da ANATEL. 4 Conclusấo. Referências.

Resumo: O presente trabalho visa compreender e analisar a efetividade de duas das mais importantes características da Agência Nacional de Telecomunicaçōes-Anatel - quais sejam a sua autonomia e a sua independência, que denotam justamente a especialidade desta autarquia, criada para exercer a função de órgăo regulador do setor, consoante mandamento constitucional insculpido no art. 21, XI, com a alteração decorrente da Emenda Constitucional $n .8$, de 15 de agosto de 1995 . A fim de subsidiar a apreciaçăo pretendida, inicia-se com uma breve passagem pela Reforma do Estado ocorrida na década de 1990 no Brasil, revisitando-se a transformação do papel de intervençāo do Estado na ordem econômica, a desestatização de serviços públicos, a privatizaçāo de empresas estataís e a criaçāo das agềncias reguladoras, sobretudo da Anatel. Posteriormente, passa-se a um relato sobre as principais características desta Agência, tais como natureza jurídica, atribuiçôes, organização, gestẫo e controle, no intuito de embasar a demarcação dos seus atributos de autonomia e independência na doutrina, na legislação e na jurisprudência, recorrendo-se também às interessantes noçôes ofertadas pelo Direito Comparado.

Palavras-chave: Agência Reguladora. Anatel Autonomia e Independência.

Abstract: This research's aim is to understand and to analyse the effectiveness of the two most important National Agency of Telecommunications - Anatel's characteristics, whose autonomy and independence indicate precisely the specialty of this entity, created to play the realm's regulatory body role by the constitutional commandment behold at the article 21 , clause XI, witch was modified by the Constitutional Amendment $\mathrm{n}^{\circ} 8$, ratified on August 15 th, 1995. In order to ensure the wanted appreciation, the study begins with a brief passage through the State Reform occurred in the 1990 decade in Brazil, revisiting the transformation of the state intervention at economic

Bacharel em Direito pela Universidade Federal do Rio Grande do Sul Especialista em Direito Público pela Faculdade IDC. Especialista em Regulaçăo de Serviços Püblicos de Telecomunicaçóes. 
order's role, the desestatization of public utilities, the state's enterprises privatization and the creation of regulatory agencies, primarily the Anatel. Later on, the paper report the main characteristics of this agency, such as legal nature, mission, organization, management and control in order to base their attributes of autonomy and independence's demarcation at the doctrine, legislation and jurisprudence, also using the interesting notions given by the Comparative Law.

Keywords: Anatel Autonomy. Independence. Regulatory Agency.

\section{Introdução}

O presente trabalho busca abordar alguns dos aspectos mais relevantes da Agência Nacional de Telecomunicaçōes ANATEL $-{ }^{2}$ quais sejam a sua autonomia e a sua independência, cujo surgimento é resultado da transformação do papel de intervenção do Estado na ordem econômica, ocorrida na década de 1990, que passa de empresário a regulador, no objetivo de atuar indiretamente nas relaçöes econômicas, no sentido de conduzi-las ao alcance dos fins consagrados em nossa Carta Constitucional, a qual arquiteta, nitidamente, um projeto de Estado Social.

Essa mudança não significa a ausência do Estado nem a adoção de uma concepção mínima ou liberal. Na verdade, trata-se de uma reforma qualitativa na sua esfera de atuação. na tentativa de aperfeiçoar a administração pública brasileira, ineficiente e gigantesca ao apagar das luzes do século XX.

Todo este contexto pode ser canalizado na desestatização dos serviços públicos, na privatização de empresas estatais e na criação das Agências Reguladoras, autarquias especiais, cujas características de dirigentes nomeados para mandatos fixos e sem possibilidade de demissão ad nutum, de ausência de recurso hierárquico impróprio de suas decisôes, de discricionariedade técnica e de poder normativo denotam a sua especialidade; sintetizadas nos atributos de independência $\mathrm{e}$ autonomia.

\footnotetext{
${ }^{2}$ Artigo resultante de adaptaçăo da monografía de conclusão do Curso de Especialização em Direito Público, realizada sob a orientaçăo do Prof Me. Alósio Zimmer Jr.
}

Cadernos do PFG em Direito UFRGS, Porto Alegre, v. 6, n. 7 e 8, p. 151 193, 2007. 
Assim nasceu a ANATEL, uma entidade da administração indireta vinculada ao Ministério das Comunicaçōes, instituída para exercer a função de órgão regulador do setor de telecomunicaçôes, abarcando a normatizaçáo, a fiscalização e o planejamento setorial. Seu surgimento foi viabilizado pela promulgação da Emenda Constitucional $n$. $^{\circ}$, de 15 de agosto de 1995, que retirou das mãos do Estado a prestação do serviço de telecomunicaçôes, permitindo sua outorga a terceiros.

Em que pese a existência das agências reguladoras desde 1996, ainda hoje não existe uma posição consolidada acerca dos contornos de sua independência e autonomia, terminologia largamente utilizada, porém sem a devida acuidade na caracterização e definição de seus limites. Dessa maneira, o escopo deste trabalho é estudá-los, fazendo um compêndio da doutrina, jurisprudência e legislação vigente, bem como das idéias contempladas nos projetos de lei e proposta de emenda constitucional em tramitaçẩo no Congresso Nacional, apoiando-se em experiências do Direito Comparado e na realidade fática vivenciada por essas agếncias, focando-se na ANATEL.

Desde logo, cabe ressaltar que a presente pesquisa visa passar ao largo da discussão crítica sobre privatização de empresas estatais, ingresso de capital estrangeiro e desestatização de serviços públicos, consubstanciados na Reforma de Estado, a fim de se concentrar na independéncia e na autonomia da ANATEL.

Assim, o estudo foi divido em duas grandes partes. Na primeira, inicia-se a análise sobre a conjuntura da Reforma de Estado, a criação das Agências Reguladoras e, especificamente, a ANATEL, passando pelas suas características, funções, estrutura, constituição, controle e peculiaridades, bem como pelo modelo regulatório adotado. Na segunda parte, centra-se na tentativa de compilar as noções existentes sobre os atributos de independência e autonomia, recorrendo-se à legislação, à doutrina e à jurisprudência brasileiras e a 
pertinentes concepções de Direito Comparado, a fim de que se possa compreendê-los e definir suas implicaçôes.

Não se tem a pretensão de esgotar o tema, mas de apenas trazer à baila algumas questões importantes sobre o assunto, extremamente em voga em razão dos terriveis acidentes aéreos ocorridos no país nos últimos meses, que desencadearam discussão sobre o papel e a eficiência das Agências Reguladoras, principalmente sobre a nomeação e possibilidade de demissăo de seus dirigentes pelo Presidente da República.

\section{ANATEL e a Concepção de Agência Reguladora}

\subsection{A reforma do Estado e a criação da ANATEL}

No final do século XX o Estado Brasileiro sofreu grandes: reformas no seu arranjo institucional, conjuntamente designadas de Reforma do Estado, cujo mote central recaiu sobre a administração pública e a forma de intervenção do estado na ordem econômica.

Essa relevante alteração do perfil estatal foi observada em todo o mundo como resposta a conjuntura mundial de crise do Estado do Bem-Estar Social ${ }^{3}$, que se arrastava desde a década de 1970 , contribuindo para uma situação deficitária e ineficiente de muitos Estados.

Grotti identifica na legislação brasileira os primeiros movimentos no intuito de inverter o modelo expansionista de Administraçäo Pública. Tem-se o Decreto $n^{\circ} 83.740$, de 18 de julho de 1979, que institui o Programa Nacional de Desburocratizaçằo, cujas alíneas " $\mathrm{g}$ " e " $\mathrm{h}$ " do seu art $3^{\circ}$ limitam a criação de entidades da administração indireta. Nessa linha, o Decreto $\mathrm{n} .91 .991$, de 28 de novembro de 1985 , dispóe sobre

\footnotetext{
${ }^{3}$ Não se pretende discutir as diferenças entre Estado Social e Welfare State apontada por alguns doutrinadores sendo estes termos utilizados como sinonimo neste trabalho. ${ }_{4}^{4}$ GROTII, Dinora Adelaide Musetti $O$ Sentiço público e a Constitução brasileira de 1988. São Paulo: Malheiros, 2003 406 p. 149-150.
} 
o processo de privatização; o Decreto $\mathrm{n}^{\circ} 95.886$, de 29 de março de 1988, estabelece o Programa Federal de Desestatização; a Lei n. ${ }^{\circ} 8.031$, de 12 de abril de 1990 , cria o Programa Nacional de Desestatização, ressaltando a transferência à iniciativa privada das atividades indevidamente exploradas pelo setor público, fulcro art $\mathbf{I}^{\circ}$, inciso $\mathrm{I}_{\text {; }}$ e a Lei $\mathrm{n}^{\circ} 9.491$, de 9 de setembro de 1997, que alterou procedimentos relativos ao Plano Nacional de Desestatização - PND -, em decorrência das emendas constitucionais promulgadas em 1995, as quais marcam a quebra do monopólio da exploração dos serviços públicos pelo Estado, conforme ver-se-á a seguir.

A autora ainda aponta com propriedade a consubstanciação do descrédito das idéias Keynesianas de intervenção do Estado na economia, oriundo da Escola de Chicago, no Consenso de Washington, que representa uma fórmula composta de dez medidas com o objetivo de acelerar o desenvolvimento econômico, energicamente recomendada pelo FMl na década de 1990, para adoçāo pelos países emergentes. As regras pregam: disciplina físcal; redução dos gastos públicos; reforma tributária; desregulamentação da economia e reforma da legislação trabalhista; defesa do direito de propriedade; câmbio livre; privatização; abertura comercial; ampliação da entrada de capital estrangeiro; e juros de mercado. ${ }^{5}$

A Reforma do Estado foi capitaneada pelo Governo Fernando Henrique Cardoso, especificamente através do Ministério da Administração Federal e Reforma de Estado MARE -, que adotou a terminologia de Estado Gerencial. Outrossim, Bresser-Pereira defende que esta é uma nomenclatura mais democrática, ${ }^{\circ}$ cuja justificativa transcreve-se:

Tornou-se comum afirmar que as reformas orientadas para o mercado, que vêm sendo realizadas desde 1980 ,

'GROTTI, O Serviço, p. 149-152.

BRESSER-PEREIRA, Luiz Carlos. A Reforma Gerencial de 1995. In: CADERNOS ADENAUER II (2001), n. 3, Butocracia e Refoma do Estado, São Paulo: Fundação Konrad Adenauer, jul. 2001. 109 p. p. 29-45. p. 30. 
importam na passagem do "Estado produtor" para o "regulador". Esta linguagem é, porém, enganosa, e tem forte sabor neoliberal, na medida em que se afirma que a reforma limita-se a privatizar serviços monopolistas ou quase-monopolistas, para, em seguida, estabelecer agências reguladoras dos preços das empresas privatizadas. Por isso, prefiro falar em uma Reforma Gerencial do Estado e, portanto, que a transiçāo do "Estado produtor" para o "Estado gerencial" vai alêm de criar agências reguladoras: é também o Estado democrático e eficiente que financia a fundo perdido os serviços sociais e a pesquisa científica e age como capacitador (enabler) da competitividade das empresas privadas.

Dessa maneira, ocorreu a redefinição do perfil estatal, abandonando-se a concepção do Estado interventor e agente econômico, conforme a dicçẩo de Faria: ${ }^{7}$

Ele deixa de ser o controlador, diretor, planejador e indutor do desenvolvimento e passa a atuar como regulador das atividades privatizadas, como balizador da concorrência, como estimulador da oferta de serviços essenciais num ambiente competitivo, como garantidor dos direitos do consumidor e como criador de oportunidades de negócios para a iniciativa privada e de investimento para o desenvolvimento tecnológico.

Assim, verifica-se uma substancial modificação do papel do Estado, no sentido de que deixa de atuar diretamente como agente econômico, principalmente na prestação dos serviços públicos, para atuar indiretamente, o chamado Estado Regulador, regulando a atividade econômica exercida por particulares. Essa intervençâo justifica-se pela importância dos serviços (serviços essenciais à população que não podem ficar somente aos cuidados de um mercado eficiente) ou pela necessidade de garantir a competiçăo em determinados setores, fazendo com que a atividade econômica coadune-se com o projeto de país previsto por nossa Magna Carta.

\footnotetext{
'FARIA, José Eduardo C. O. (Org.). Regulaçäo, direito e democracia. São Paulo: Fundação Perseu Abramo, 2002. 104 p. 8.
} 
Deve-se destacar que a desestatização ocorrida no país com a entrega da prestação de serviços públicos ao setor privado e a privatização de empresas estatais não significam a retirada do Estado da economia, nem o abandono da concepção de Estado Social. Nesse sentido, Aragão ${ }^{8}$ afirma:

Refutamos assim a correlação necessária que às vezes se faz entre Estado social e estatizaçao. A democraticidade do Estado, apesar de não excluir, não pressupōe a estatização. A ordem econômica constitucional dos Estados Democráticos deixa, dentro dos limites já assinalados, espaço para uma maior ou menor estatização ou intervençăo na economia.

Outrossim, Barroso ${ }^{9}$ ensina que a delegação às empresas privadas não retira a natureza de serviço público, na medida em que o Estado "conserva responsabilidades e deveres em relação a sua prestação adequada", e Sundfeld ${ }^{10}$ esclarece que a implantação das agências não importa em processo de privatização, cuja recíproca também não é verdadeira.

Marques Neto destaca que nessa nova configuração o Estado "estará presente, porém definido os marcos regulatórios. O que será substancialmente distinto será a forma de intervenção, seja no que concerne aos seus pressupostos, como objetivos $e$ instrumentos". ${ }^{11}$

Ao abordar o tema, complementa Mattos:12

\footnotetext{
ARAGAO, Alexandre Santos de. Agências Reguladoras e a Evolução do Direito Administrativo Econômico. 2 ed. 2 tir Ruo de Janeiro: Forense, 2004.509 p. 58 .

BARROSO, Luís Roberto. Apontamentos sobre as Agências Reguladoras. In: MORAES, Alexandre de (Org). Agências Reguladoras. São Paulo: Atlas, 2002.170 p. 109-131, p. 116-117.

in SUNDFELD, Carlos Ari. Introduça às Agênclas Reguladoras. In: SUNDFELD, Carlos Ari (Coord) Direlto Administrativo Econômico. 1 ed 2 tír Sã Paulo: Malheiros, 2002. 405 p. 17-38. p. 19

"MARQUES NETO, Floriano Peixoto de Azevedo. Agências reguladoras: instrumentos do fortalecimento do Estado. Porto Alegre: ABAR, 2000. p. 53.

12 MATTOS, Fulo Tódescan Lessa. Regulaçăo Econômica e Democrática. In: FARIA, José Eduardo C O. (Org) Regulaçao, direto e democracia. Sáo Paulo: Fundaçăo Perseu Abramo, 2002. 104 p. 43-66. p. 56.
} 
Diante desse quadro normativo, a mudança na forma de atuação do Estado como agente normativo e regulador da atividade econômica, conforme previsto no artigo 174 da Constituição Federal de 1988, constitui o principal elemento de transformação jurídico-institucional introduzida pelo projeto de reforma do Estado no Brasil. E o que caracteriza e define tal mudança é a criação de agências de regulação como órgãos responsáveis por certos setores da economia, principalmente por aqueles caracterizados como de infra-estrutura e serviços públicos, com funçóes normativas e reguladoras orientadas especialmente pelos princípios constitucionais da livre concorrência e da defesa do consumidor.

Cabe uma pequena digressão histórica, a fim de compreender a evolução da forma de intervenção do Estado brasileiro na economia. Lehfeld ${ }^{13}$ menciona que a estatizaçắo iniciou-se a partir da década de 30 do século passado, pois até então a prestação dos serviços públicos era realizada pela iniciativa privada, sob regulamentação. Posteriormente, numa fase organizacional para atendimento das necessidades coletivas, criou-se as autarquias, conforme os ensinamentos de Marques $\mathrm{Neto}_{,}{ }^{14} \mathrm{e}$, mais adiante, as sociedades de economia mista e empresas públicas, para concretizar o novo papel do Estado, qual seja de explorador de atividade econômica. No próximo passo da evolução, tem-se o Estado Regulador.

Em que pese as palavras do então Ministro do MARE, anteriormente referidas, a vinculação da terminologia "Estado Regulador ${ }^{n}$ à ideologia neoliberal não procede, uma vez que regulação não pode ser compreendida como privatização

\footnotetext{
MEHFELD, Lucas de Souza. As novas tendências na regulamentaçáo do sistema de telecomunicaçoes pela Agencia Nacional de Telecomunicaçóes (ANATEL). Rio de Janeiro: Renovar, 2003.232 p. 149.

i4 MARQUES NETO, Floriano Peixoto de Azevedo. Balanço e Perspectivas das Agências Reguladoras no Brasil Revista Eletronica sobre a Reforma do Estado, Salyador, Instituto de Direito Fúblico da Bahia, n. 1 , marco, 2005. Disponivel na Intemet: $<$ http//wwidireitodoestado.com $>$. Acesso em: 15/07/2006. 14 p. 3-4.
} 
e enxugamento do Estado. Precisa ser entendida como um fenômeno maior de transformação do perfil de intervenção econômica do Estado, que não significa a adoção de um Estado Liberal, nem Mínimo.

Para entender o novo perfil de intervenção estatal, faz-se necessário trazer a cotejo uma definição da atividade de regulação. Para tanto, adota-se o conceito apresentado por Aragão: ${ }^{15}$

[...] regulação estatal da economia é o conjunto de medidas legislativas, administrativas e convencionais, abstratas ou concretas, pelas quais o Estado, de maneira restritiva da liberdade privada ou meramente indutiva, determina, controla ou influencia o comportamento dos agentes econômicos, evitando que lesem os interesses sociais definidos no marco da Constituiçẫo e orientando-os em direções socialmente desejáveis.

Cita-se ainda sobre o tema regulação, a lição de Campos e Santiago Junior: ${ }^{16}$

Em sua versão contemporânea, a regulação pode ser entendida como o processo composto da desregulamentação de um segmento da economia funcionando de modo planificado, seguida de novo estabelecimento de regras de funcionamento, com vistas a preservar condiçôes de concorrência e, conseqüentemente, eficiência. Note-se que, neste texto, a palavra regulamentação está associada à idéia de funcionamento planificado de um setor da economia. Essa planificaçầo pode ser obtida por meio de um conjunto de normas e procedimentos originados no interior do Estado, traduzindo em leis, decretos, portarias, einstruçôes normativas; e/ou pela presença direta do Estado no sistema produtivo, através da criação de empresas públicas, sociedades de economia mista, fun" daçōes e etc.

\footnotetext{
isARAGAO, Op. Cit., p. 29.

"CAMPOS, Anna Maria; SANTIAGO JUNIOR, Dércio. Regulação gradual: a opçăo de aprendizagem. In: CADERNOS ADENAUER II (2001), n. 3 , Buroctacia e Reforma do Estado, São Paulo: Fundacão Konrad Adenauer, jul 2001.109 p. 97-108. p. 109.
} 
Neste contexto, surgem as Agências Reguladoras - ARs no Brasil, tanto na esfera federal como na estadual e municipal, concebidas como entidades autárquicas em regime especial. Essas são entidades criadas por lei, algumas inclusive com previsão constitucional como a ANATEL e a Agência Nacional do Petróleo, Gás Natural e Biocombustíveis ANP - e a sua nota de especialidade, a qual deve "ater-se ao ordenamento jurídico-constitucional vigente" ${ }^{17}$ concentra-se em maior autonomia. Moraes ${ }^{18}$ afirma que "a grande novidade das Agências Reguladoras consiste em sua maior independência em relaçâo ao Poder Executivo, apesar de fazer parte da Administração Pública Indireta". Ferreira Filho ${ }^{19}$ ainda aponta que o objetivo dessas agências é a independência no tocante às "vicissitudes político-partidárias".

Uma importante característica da criação das ARs é a segregação entre o órgão que normatiza, fiscaliza e planeja, ou seja, que regula àquela determinada atividade econômica, daquele que efetivamente presta o serviço, o que não ocorria no monopólio estatal. Macedo ${ }^{20}$ clarifica:

Desse modo, a saída do Estado na atuação econômica, especialmente naquelas atividades que configuravam serviço público, acabou por evidenciar a separaçăo do que antes convivia conjuntamente: o órgão regulador eo prestador de serviço. Tal evidencia-se, claramente, no setor de telecomunicaçôes, em que o antigo Sistema

\footnotetext{
${ }^{17}$ Observação de ARAUJO, Edmir Netto. A Aparente Autonomia das Agências Reguladoras In MORAES, Alexandre (Org). Agências Reguladoras Sắo Paulo: Allas, 2002. 170 p 39-55. p. 39 .

${ }^{18}$ MORAES, Alexandre de. Agencias Reguladotas. In: MORAFS, Alexandre de (Org). Agências Reguladoras, Săo Paulo Atlas, 2002.170 p. 13.36.

${ }^{19}$ FERREIRA FILHO, Manoel Conçalves. Reforma do Estado: o papel das agências reguladoras e fiscalizadoras. In: MORAES, Alexandre de (Org). Agências Reguladoras. Saao Paulo: Atlas, 2002: 170 p. 133-143. p. 110.

${ }^{20}$ MACEDO, Jaqueline Mainel Rocha de. Discricionariedade Técnica e Funçäo Nomativa em Setores Regulados, e sua Identificação na Lei Geral de Telecomunicaçōes. In: ARANHA, Márcio lorio (Org.). Direito das Telecomunicaçöes: Estrutura Institucional Regulatóna e Infra-estrutura das Telecornunicaçöes no Brasil. Brasflia: JR Grafica, 2005. 250 p. 121-187. p. 124.
} 
Telebrás concentrava a prestação do serviço de telefonia e a expediçấo de normas regulamentadoras.

A separação das duas faces de ação estatal configura, então, a distinção entre intervencionismo direto e o intervencionismo indireto. $O$ primeiro ligado à prestação direta de determinado serviço pelo Estado, e o segundo concernente à atividade de fiscalização, regulamentaçāo e monitoramento da atividade económica.

Moreira e Maças ${ }^{21}$ esclarecem os objetivos de uma agência reguladora, para a qual adotam a terminologia de Autoridade Administrativa Independente - AAI. Rezam os autores portugueses:

Pode dizer-se que as autoridades administrativas independentes visam corresponder a necessidades que se fazem sentir em dois domínios fundamentais: por um lado, assegurar a regulação de sectores sensíveis ou estratégicos, cuja actividade tem de se desenvolver num ambiente de liberdade e concorrência; por outro lado, proteger os direitos dos administrados, em especial, os novos direitos à transparência e à informação, contra o risco de actuação burocrática arbitrária da administração.

Outra nota fundamental dessas entidades é o seu poder normativo que implica a criação de ordenamentos setoriais e que decorre diretamente da sua lei criadora, conforme ensinamento de Rezio: ${ }^{22}$

[...] a pluralização das fontes normativas conjugada à descentralizaçáo do aparato estatal, pela criação de entes ou órgẫos autônomos independentes, representam o grande paradigma finalístico do Estado Moderno. Nesse contexto, a normatizaçäo setorial constitui eficaz instrumento

\footnotetext{
MOREIRA, Vital; MACAS, Fernanda. Autoridades Reguladoras Independentes: Estudo e Projecto de Lei-Quadro. Coimbra Coimbra Editora, 2003.318 p. 24.

22PEZ1O, Juliana Oliveira. O Poder Nomativo do Executivo $e$ a Separação de Poderes. In: ARANHA, Márcio lorio (Org.). Direito das Telecomunicaçöes: Estrutura Institucional Regulatória e Infra-estrutura das Telecomunicaçées no Brasil. Brasilia: JR Grélica, 2005. p. 81-120. p. 101 e 112.
} 
regulatório diante dos mecanismos, até então, adotados pelo Estado.

\section{$[\ldots]$}

As leis atributivas de poder normativos às entidades reguladoras possuem baixa densidade normativa a fim de propiciar o desenvolvimento de ordenamentos setoriais, estabelecendo, apenas, parâmetros bem gerais de regulamentação a ser efetivada pelo ente regulador uma vez que a competência normativa da entidade encontra-se prevista em sua lei de criação.

A nossa Norma Fundamental consagrou, no art. 170, os princípios da ordem econômica, fundada na livre iniciativa, destacando-se a livre concorrência, a soberania nacional, a propriedade privada, a função social da propriedade, o pleno emprego e a defesa do consumidor, entre outros. Veja-se que a livre iniciativa nunca impediu a intervenção estatal, uma vez que ao seu lado se impõe a observância aos ditames da justiça social. Outrossim, os princípios justificam, inclusive, a exploração da atividade economica de forma monopolista pelo Estado.

$O$ art. 174, caput, da Constituição Federal contempla essa nova configuração, ao determinar que o Estado, como agente normativo $€$ regulador, exerça as funções de fiscalização, incentivo e planejamento.

Com a edição das Emendas Constitucionais n. ${ }^{\circ} \mathrm{s}$ 5, $7 \mathrm{e}$ 8, promulgadas em 15 de agosto de 1995, substancialmente, ocorre a quebra do monopólio de exploraçâo dos serviços públicos pelo Estado, permitindo, por exemplo, que os serviços de gás canalizando (Emenda Constitucional n. ${ }^{\circ}$ /95) e de telecomunicaçōes (Emenda Constitucional n. ${ }^{\circ} 8 / 95$ ) pudessem ser explorados por empresas privadas, através de concessäo, autorizaçäo ou permissão. Igualmente, amplia-se a possibilidade de participação do capital estrangeiro nas concessōes, com a modificação do conceito de empresa brasileira. ${ }^{23}$

${ }^{23}$ Nesse sentido, ver GROTTI, O Serviço, p. 150

Cadernos do PPG em Direito UFRGs, Porto Alegre, v. $6, n .7$ e 8, p. 151-193, 2007. 
Embora o intuito deste trabalho não ser a discussão crítica sobre todo o processo de Reforma do Estado vivenciado pelo nosso país, cabe demonstrar a existência de vozes destoantes como Grau, que profere crítica à Emenda Constitucional $n: 8 / 95^{\circ}: 24$

A Emenda Constitucional $n^{\circ} 8 / 95$ conferiu novas redaçōes ao inciso XI e à alínea "a" do inciso XII do art. 21 da Constituição.

O inciso XI referia concessão a empresas sob controle acionário estatal dos "serviços telefônicos, telegráficos, de transmissâo de dados e demais serviços públicos de telecomunicaçôes". A nova redaçâo conferida ao preceito, que menciona singelamente serviços de telecomunicaçōes, refere simplesmente a autorização, concessão ou permissão dos serviços, o que importa em que possam vir ser privatizados. Este terá sido, seguramente, o objetivo maior visado pelo Poder Executivo na proposição da reforma constitucional, em coerência com o programa neoliberal de internacionalização econômica. $O$ interesse das multinacionais sobretudo na telefonia celular é bem marcante, articulando-se com grande eficiência.

Bonavides reforça o caráter social presente na Carta Constitucional de 1988, a qual não pode ser afastada do ordenamento. Assim, todo e qualquer instituto deve ser interpretado conforme os preceitos contidos nela. Prega o autor ${ }^{25}$ :

A Constituiçâo de 1988 é basicamente em muitas de suas dimensôes essenciais uma Constituição do Estado Social. Portanto, os problemas constitucionais referentes a relaçóes de poderes e exercício de direitos subjetivos têm de ser examinados e resolvidos à luz dos conceitos derivados daquela modalidade de ordenamento. Uma coisa. é a Constituiçăo do Estado liberal; outra a Constituição do Estado Social. A primeira é uma Constituição antigoverno

\footnotetext{
${ }^{24} \mathrm{GRAU}$. Eros Roberto. A Ordem Econômica na Constituição de 1988. 9 ed. rev. e atual São Paulo Malheiros 2004. 351 p. 267.

rBONAVIDES, PAULO Curso de Direito Constitucional 9 ed. São Paulo: Malheiros Edirores, 2000.793 p. 366.
} 
e anti-Estado; a segunda uma Constituição de valores refratários ao individualismo no Direito e ao absolutismo no Poder.

Dessa forma, as Agências, como todo e qualquer instituto jurídico do nosso ordenamento, precisam ser pensadas e avaliadas dentro da concepção de um Estado Social, a fim de concretizar o projeto de país insculpido na Carta Política de 1988.

Antes de passar-se ao estudo da ANATEL, cabe mais uma consideraçâo. Existe uma espécie de preconceito em relaçâo a essas entidades, possivelmente gerada pela inspiração e adoção da nomenclatura norte-americana ${ }^{26}$ e pela alegação de que representam a opção pelo Estado Liberal, fato que não subsiste a uma pesquisa aprofundada sobre o tema. Barroso $^{27}$ adverte:

A questão que se vive hoje da desconstrução do Estado brasileiro, por ruim que possa ser, não é uma opção ideológica, é uma inevitabilidade histórica. É preciso, assim, pela primeira vez na história do Brasil, publicizar o Estado, não importa o tamanho que ele tenha.

Reforçando os argumentos trazidos anteriormente, leciona Sundfeld ${ }^{28}$ :

Não é correto supor que agência reguladora seja sinônimo de processo de privatização, e vice-versa. Autoridades com poderes de regulação existem para todos os setores, não só para os privatizados (mencionem-se os órgáos de defesa da concorrência e os voltados ao mercado financeiro). Agèncias Reguladoras existem em países que nunca conheceram os fluxos de estatização e privatizaçấo, como os Estados Unidos. Privatizações foram

\footnotetext{
26) $\mathrm{Ver}$ ARAGAO, Op: Cit., p. 37.

${ }^{2}$ BARROSO; Op. Cit. p. 110 .

28SUNDFELD, Carlos Ari Introdução às Agências Reguladoras. In SUNDFELD, Carlos Ari (Coord.). Direito Administrativo Económico. I ed. 2 tir. São Paulo: Malheiros, 2002. 405 p. 17-38. p. 19.
} 
implementadas sem que o Estado se preocupasse em ampliar sua função regulatória, que por o setor não o justificar (caso das desestatizaçōes de empresas siderúrgicas e petroquímicas federais no Brasil dos anos 80 ), quer por opção política (caso das privatizaçôes de serviços básicos na Argentina da década de 80 ).

A constituição desses órgãos revela uma idéia de afastamento das vicissitudes do jogo político-partidánio, uma vez que regulam setores estratégicos para a sociedade, sendo consideradas entidades de Estado, ao invés de entidades do Governo. Setores como telecomunicaçōes, energia elétrica, petróleo e transportes (regulados, respectivamente, pela ANATEL; Agência Nacional de Energia Elétrica - ANEEL; ANP; Agência Nacional de Transportes Terrestres - ANTT; Agência Nacional de Transportes Aquaviários - ANTAQ; e Agência Nacional de Aviação Civil - ANAC) entre outros, exigem investimentos a longo prazo, que necessariamente ultrapassam o lapso temporal de um mandato. Dessa forma, năo podem ficar a sua mercê, sob pena de comprometer o desenvolvimento e o crescimento do País. Nesta esteira, corrobora Marques Neto: ${ }^{29}$

A razão para tanto nắo nos parece muito complexa. Dissemos há pouco que o surgimento destes órgãos coincide com um novo estágio de regulação estatal marcado pela separaçấo entre o prestador do serviço essencial e o ente encarregado de regulá-la. Em se tratando de serviços ou atividades de relevância coletiva, de elevado impacto social, teremos sempre uma relação tripartida. Há i) o produtor da utilidade pública; ii) o seu consumidor; e ii) o poder público.

A criação da ANATEL foi possibilitada pela Emenda Constitucional n ${ }^{\circ} 8$, de 15 de agosto de 1995 , a qual alterou a redação dos incisos XI, alínea a, e XII do art 21 da Constituição

\footnotetext{
MARQUES NETO, Flonano Peixoto de Azevedo. Agenctats reguladoras: instrumen tos, p. 29.
} 
Federal, permitindo a outorga de serviços de telecomunicações, através de concessão, permissão ou autorização, a entidades privadas. Adernais, determinou a necessidade de lei para definir essa outorga, a qual também deveria dispor sobre a organizaçâo dos serviços de telecomunicaçōes e a criação de órgão regulador, entre outros aspectos institucionais.

Em atendimento ao mandamento constitucional, em 16 de julho de 1997, foi editada a Lei . $^{\circ} 9.472$, conhecida como Lei Geral de Telecomunicaçoes - LGT - criando a Agência Nacional de Telecomunicaçóes, autarquia federal em regime especial, integrante da administração indireta e vinculada ao Ministério das Comunicações, com função de órgão regulador.

Oportuno trazer aqui um questionamento, ainda que raramente apontando, que seria a contradição em estabelecer uma entidade, dotada de personalidade jurídica, em relação ao texto da Carta Política que prevê a criação de órgão regulador. ${ }^{30} \mathrm{~A}$ criação de órgãos na administração decorre do fenômeno da desconcentração administrativa, não possuindo personalidade jurídica e ficando hierarquicamente subordinados ao órgão ao qual pertencem, enquanto que a instituiçâo de autarquias corresponde à descentralização da administraçäo, criando-se pessoas jurídicas para o exercício de determinadas atividades, restando estas vinculadas a algum orgão do respectivo poder, sem relação de hierarquia, ${ }^{3 .}$ mas tão-somente de supervisâo, de tutela.

Interessante mencionar que no art. $2^{\circ}$, inciso IV, da LGT consta a obrigação do Poder Público em fortalecer o papel regulador do Estado.

\subsection{A ANATEL e o Modelo Regulatório}

A ANATEL compete organizar a exploração dos serviços de telecomunicaçôes, por expressa delegação da Uniäo, nos

\footnotetext{
3TMMER JƯNIOR, Aloisio. Direito Administrativo. Potto Alegre: Verbo, 2007. $432 \mathrm{p}$. 154.

${ }^{3}$ Sobre o assunto, ver ZIMMER JÜNIOR, Op. Cit., p. 130161.
} 
termos do art. $1^{\circ}$, caput, da LGT, o que inclui a regulamentação e a fiscalização do setor, entre outros aspectos.

A LGT no seu art. $8^{\circ}, \S 2^{\circ}$, destaca que a natureza de autarquia especial caracteriza-se, in verbis: "por independência administrativa, ausência de subordinação hierárquica, mandato fixo e estabilidade de seus dirigentes e autonomia financeira". O Decreto n. 2.238, de 07 de outubro de 1997, que aprovou o Regulamento da Agência Nacional de Telecomunicaçōes e marcou a instalação da entidade, contém disposição semelhante no seu art. $1^{\circ}, \S 2^{\circ}$.

$\mathrm{O}$ órgắo máximo da ANATEL é o Conselho Diretor, composto por 5 conselheíros, equiparados a SecretáriosExecutivos de Ministérios, ${ }^{32}$ dentre os quais será nomeado o Presidente, decidindo por maioria absoluta e năo existindo a possibilidade de abstenção. Todos os conselheiros serão brasileiros, de reputação ilibada, com formação universitária e elevado conceito no campo de especialidade. São escolhidos pelo Presidente e por ele nomeados, após sabatina do Congresso Nacional, consoante disposto no art. $23 \mathrm{da}$ LGT e art. $5^{\circ}$ da Lei ${ }^{\circ}{ }^{\circ} 9.986$, de 18 de julho de 2000 , que dispóe sobre a gestão de recursos humanos das Agências Reguladoras, também chamada de Lei Geral das Agências - LGA.

O mandato dos conselheiros é näo coincidente e de 5 anos. A vedação da recondução foi retirada pela LGA, a qual suprimiu a parte final do caput do art. 24 da LGT. Para estabelecer a não coincidência, os mandatos iniciais foram estabelecidos com prazos de duração diferenciados, nos termos do art. 25 da LGT.

A LGA determinou, no art. $9^{\circ}$, que os conselheiros só perdem o mandato em caso de renúncia, condenação judicial transitada em julgado ou processo administrativo disciplinar, autorizando que a lei de criação de cada Agência

\footnotetext{
${ }^{32} \mathrm{~A}$ eles são assegurados os mesmos direitos, vantagens, prerrogativas e tratamento, inclusive protocolar, nos temos do paragrafo único do art. 20 da IGT.
} 
elencasse outras condições. Embora a LGT, ainda que anterior, se coadunasse perfeitamente com as normas gerais estabelecidas naquela, ressalvando outra hipótese no $\S 1^{\circ}$ do artigo 26 , além de outras estabelecidas por leis criminais ou pela Lei de Improbidade Administrativa, Lei n. ${ }^{\circ} 9.429$, de 2 de junho de 1992, qual seja a inobservância dos deveres e proibiçöes inerentes ao cargo, inclusive no tocante ao descumprimento das políticas setoriais estabelecidas pelo Governo e pelo Parlamento, a LGA revogou expressamente todo o art. 26 da LGT,

O Conselho é chefiado por um Presidente, escolhido dentre seus membros, nomeado pelo Presidente da República e investido na função pelo prazo fixado no ato de nomeação, consoante \$ único do art. $5^{\circ}$ da LGA e a revogação expressa do art. 31 da LGT que estabelecia o prazo de 3 anos e a impossibilidade de recondução na função de Presidente do Conselho.

A LGT estabelecia nos arts. 28 e 31 o regime de incom. patibilidade dos dirigentes, restando vigente apenas o art. 31 que proibe a representação de pessoas $\mathrm{e}$ interesses por exconselheiros até um ano após o término do mandato e a utilização de informações privilegiadas obtidas em decorrência do cargo. $\mathrm{O}$ art. 28 vedava o exercício de qualquer outra atividade profissional, empresarial, sindical ou de direçäo política, bem como a existência de interesse significativo, direto ou indireto, em empresa de telecomunicaçōes, tendo sido expressamente revogado pela LGA.

A LGA impóe um período de quarentena aos ex-dirigentes, definido em quatro meses, durante o qual ficarão vinculados à respectiva agência e receberão remuneração compensatória equivalente ao cargo ocupado, nos termos do art. $8^{\circ}$, com redação dada pela Medida Provisória $n^{\circ} 2.216$ $37 / 2001$.

À Agência também foi destinada a administraçầo exclusiva do Fundo de Fiscalização das Telecomunicaçōes FISTEL -, cujas taxas são devidas em razão da fiscalizaçăo exercida. 
Interessante notar que a LGA também determina que a licitação nas agências poderá ser realizada nas modalidades de consulta e pregão, observados os arts. 55 e 58 da LGT, e nos termos de regulamentação própria.

O organograma da Agência contempla um Conselho Consultivo, no qual a sociedade tem assento, uma Procuradoria, uma Corregedoria, uma Biblioteca e uma Ouvidoria, além das unidades descentralizadas.

Inicialmente, a LGA determinou que o quadro pessoal efetivo da agência seria regido pela Consolidação das Leis do Trabalho - CLT - em regime de emprego público, disposição com eficácia suspensa pela liminar ad referendum do Plenário do STF na ADI 2310, de Relatoria do Ministro Carlos Velloso, a qual foi julgada prejudicada, em face da edição da Lei $n$. 10.871 , de 20 de maio de 2004 , que impôs o regime estatutário aos integrantes do quadro pessoal efetivo das Agências Reguladoras, este sim, em consoante orientação do STF, compativel com a atividade desenvolvida por estas entidades, qual seja, essencialmente, o exercício do poder de polícia administrativa.

O modelo regulatório do setor de telecomunicaçōes adotado no Brasil impõe um papel multifacetado e interdisciplinar ao órgão regulador, na medida em que concentra a regulação econômica, técnica, de acesso ao mercado e de proteçăo da concorrência ${ }^{33}$ esta última em interação com o Conselho Administrativo de Defesa Econômica-CADE. Dessa forma, à ANATEL incumbe diversas atribuiçôes, dentre as quais: controle, gerenciamento e revisão de tarifas dos serviços prestados em regime público (concessionárias do serviço de telefonia fixa comutada); expedição de atos de outorga, administração do espectro de radiofrequências e estabelecimento de metas e padrōes de qualidade; regulamentação

\footnotetext{
3ANATEL. Curso de Formaçâo para os Candidatos ao Cargo de Especialista em Regulação de Servicos Públicos de Télecomunicaçóes. Módulo V: Defesa da Concorrência em Telecomunicaçóes. Instrutores: Carlos Jacques Gomes, Daniela Arbex e Miguel Mattos, Brasília: CESPE, 2005. 67 p. 53.
} 
da interconexão; e a repressão de infraçōes à ordem econômica e aos direitos dos usuários. Estas competências, insculpidas nos incisos do art 19 da LGT representam, respectivamente, as quatro esferas de regulaçâo anteriomente citadas.

Cabe aludir à função antitruste da Agência, que ao disciplinar o setor deve observar os princípios da ordem econômica, cujas normas gerais, quando não conflitantes com o disposto na LGT, também se aplicam às telecomunicaçôes. Neste ponto, o órgão regulador abarca o papel de garantir - acesso de novas prestadoras, denominado de regulação de acesso ao mercado, bem como de proteção da concorrência. Assim, observa-se uma interessante interface com a autoridade antitruste brasileira, $\mathrm{CADE}$, organizado pela Lei n. 8.884/94, de 11 de junho de 1994.

A ANATEL, na matéria referente ao setor de telecomunicações, substitui a Secretaria de Direito Econômico do Ministério da Justiça - SDE - ou a Secretaria de Acompanhamento Econômico do Ministério da Fazenda, dependendo do caso, respondendo pela instauração e pela instrução do processo, cujo julgamento é atribuição do CADE.

Tendo em vista as competências regulatórias exercidas pela ANATEL, demonstra-se a adoção da configuração institucional chamada de isenção antitruste, ${ }^{34}$ na medida em que a Agência também aplica a lei de proteção da concorrência. Ressalta-se que a aplicação não é exclusiva do órgão regulador nem abarca o julgamento destes processos, limitando-se à instauração e à instruçẩo dos mesmos. $O$ Poder decisório continua designado à autoridade antitruste. Em face destas peculiaridades, verifica-se uma aproximação com o Modelo de Competências Concorrentes, no qual ambas entidades aplicam a legislação concorrencial, cuja atuação de uma não afasta a competência da outra. ${ }^{35}$

Para Grotti ${ }^{36}$ a atividade das ARs abarca uma regulação tripla: regulação dos monopólios, regulação para a

\footnotetext{
ANATEL Op. Cit, p.52.

${ }^{35}$ ANATEL, Op. Cit., p. $65-66$.

3 GROTT, O Serviço, p. 157.
}

Cadernos do PPG em Direito UFRGS, Porto Alegre, v. $6, n$. 7 e 8, p. 151-193, 2007. 
competição e a regulação social. Respectivamente, seus objetivos são: atenuar os efeitos das forças de mercado, assegurar e promover a concorrência e universalizar os serviços.

Coutinho $^{37}$ destaca a importância da regulação social, especialmente no contexto em que foi implementada a privatização na América Latína, no qual se encaixa o processo de desestatização e de privatização sofrido pelo Brasil na última década. Prega o autor:

A forma como as privatizaçōes foram implementadas na América Latina em geral preteriu à universalização em faỵor da maximização do vălor das estatais em leilão. As conseqüências disso são de difícil antecipação, mas há claros indícios de que năo haverá inclusão da população de baixa renda à rede de serviços públicos como resultados das reformas, a não ser que os escopos da regulação econômica passem a valorizar uma racionalidade distinta.

Uma regulaçẫo econômica de conteúdo verdadeiramente redistributivo deve criar mecanismos rígidos de universalização dos serviços, bem como de investimentos em expansão das infra-estruturas o mais independente possivel de fatores políticos ou econômicos de curto prazo.

Intrigante questảo se coloca em relaçäo à existência de serviços de telecomunicações de interesse coletivo que podem ser prestados, concomitantemente, em regimes jurídicos de direito privado e direito público, nos termos dos arts. 63 e 64 da LGT A diferenciação reside no tipo de outorga do serviço e nas obrigaçốes da prestadora. Atualmente, o único exemplo é o Serviço de Telefonia Fixa Comutada, que no regime público, exclusiva hipótese expressamente contemplada pela LGT, é executado mediante concessão ou permissão, atribuindo-se à prestadora as obrigações de universalidade e continuidade, as quais inexistem no regime privado, outorgado mediante autorização. Esta diferenciação de regimes é

\footnotetext{
"CouTINHO, Diogo $R$ Privatizaçăo, regulaçáo e o desafio da universalização do serviço público no Brasil. In: FARIA, José Eduardo (Org). Regulação, direâto e democracia. São Paulo: Fundação Perseu Abramo, 2002. 104 p. 67-94 p. 93.
} 
apontada como inconstitucional por Aguillar, ${ }^{38}$ porque se admitiria a prestaçâo de um serviço público pela iniciativa privada, sem submissão aos preceitos do art. 175 da Constituição. No entanto, tal questão não tem sido objeto de debate.

A ANATEL submete-se ao controle do Poder Judiciário, do Poder Legislativo e do próprio Poder Executivo, como toda entidade integrante da administração pública. No entanto, constatam-se algumas particularidades em face do seu regime especial que lhe garante maior autonomia, tentando afastar a ingerência do jogo político-partidário. Nesta esteira, Marques $\mathrm{Neto}^{39}$ ressalta a impropriedade do argumento de ausência de controle sobre as agências reguladoras, que sấo fiscalizadas tanto interna quanto externamente.

Para esse autor, ${ }^{10}$ o controle divide-se em quatro espécies: de gestäo, de cumprimento das políticas públicas, contra abusos e ilegalidades e relativo ao alcance das finali-dades e metas da regulação.

O Poder Judiciário atua controlando a legalidade de seus atos. Não se pretende discutir a sindicabilidade do mérito dos atos administrativos, merecendo, nesse caso, destaque a discricionariedade técnica do órgảo regulador, uma vez que regula um setor extremamente dinâmico e tecnológico, sobre o qual o juiz não tem condições técnicas de adentrar, v.g., questões tecnológicas.

Neste sentido, Barroso ${ }^{41}$ aponta:

É bem de ver que, em matéria de agências, é decisivo que o Judiciário seja deferente em relação às decisōes administrativas. Ou seja, o Poder Judiciário somente deverá invalidar decisăo de uma agência reguladora quando evidentemente ela não puder resistir ao teste de razoabilidade, moralidade e eficiência. Fora dessas hipóteses,

\footnotetext{
3. AGULLLAR, Fernando Herren. Controle Social de Serviços Públicos. São Paulo: Editora Max Limonad, 1999.302 p. 273.

${ }^{9}$ MARQUES NETO, Agencias reguladoras: instrumentos, $\mathrm{p} .55$.

MARQUES NETO, Balanço, p. 12.

${ }^{4}$ BARROSO, Op. Cil., p. 127.
} 
o Judiciário deve ser conservador em relação às decisōes das agências, especialmente em relaçăo às escolhas informadas por critérios técnicos, sob pena de cair no domínio da incerteza e do subjetivismo.

Com relação à fiscalização exercida pelo Poder Legislativo, menciona-se a participação da Agência nas comissōes e audiências públicas no Congresso e a prestação de informaçōes, bem como a prerrogativa contemplada no art. 49 , inciso $\mathrm{V}$, que possibilita ao Congresso sustar ato normativo do Poder Executivo que exorbitem do poder regulamentar ou dos limites da delegação legislativa. Outrossim, o Parlamento também conta com auxilio do Tribunal de Contas da Uniăo, fulcro art. 71 da Constituição Federal.

Aqui se ressalta a atuaçẫo do TCU em relação às agências reguladoras, a qual é balizada por 22 diretrizes constantes do controle de regulação proposto pela INTOSAI - Organização Intemacional das Entidades Fiscalizadoras Superiores - na qual se inclui o TCU, dentre as quais se destacam: aquisição de competência técnica pela entidade de fiscalização; competência técnica, integridade, imparcialidade e poderes do órgão regulador; universalidade, segurança e qualidade do serviço; eficiência, custos e investimento das prestadoras dos serviços; controle de preços; arcabouço regulatório; e desenvolvimento da competição. ${ }^{42}$

No tocante à ANATEL, o TCU tem sido bastante incisivo, a fim de que a entidade se torne mais eficiente e atenda aos anseios dos usuários dos serviços de telecomunicações, conforme pode ser constatado nas conclusões do relatório da auditonia operacional de 2006 - Acórdão n. ${ }^{\circ} 2.109 / 2006$, constante da Ata 46/2006 (Plenário - Sessão 14/11/2006 Aprovaçấo 22/11/2006 - Dou 23/11/2006):

\footnotetext{
BRASIL TRIBUNAL DE CONTAS DA UNIÄO. O Controle Extemo das Agências Reguladoras: questôes relevantes sobre o setor elétrico e de petróleo e gás natural. Brasilia: TCU, SEFID, 2003.28 p. Disponível em: <http//www2.tcu.gov.br/portal/ page? pageid $=33,4564796$ dad=portale schema $=$ PORTAL>. Acesso em: 17/10/ 2007. p. $9-11$.
} 
538. Conclui-se das observações apresentadas neste relatório que existem limitaçōes nos processos de regulamentação, de fiscalização e de sanção que comprometem a atuação da ANATEL no acompanhamento da qualidade da prestação dos serviços de telecomunicações pelas empresas operadoras. Soma-se a essas constatações a não prionização de uma política de educação dos usuários e o fato do órgão regulador não ter como foco os usuários na execução dos processos acima descritos.

Dentre as extensivas recomendaçóes expedidas pelo Tribunal à ANATEL, destacam-se as abaixo colacionadas:

9.1.6. com fulcro no art. $3^{\circ}$ da Lei $9.572 / 1997$, formule e apresente a este Tribunal, no prazo de 180 (cento e oitenta) dias contados da ciência deste acórdão, diretrizes para promoção de uma política de informação e educação dos usuários de telecomunicaçōes, que contemplem, prioritariamente, os seguintes aspectos:

9.1.6.1. maior participação dos usuários nas decisões regulatónias da ANATEL;

9.1.6.2. reativaçẫo do Comitê de Defesa dos Usuários;

9.1 6.3. a disseminação dos direitos e deveres dos usuários e das obrigaçōes das prestadoras relativamente a esses serviços;

9.1.6.4 política de incentivo à criação de conselho de usuários junto às prestadoras dos principais serviços de telecomunicações e política de educação dos participantes desses conselhos;

9.2.2.4. revise as estratégias de fiscalização para atender os aspectos mais cobrados pelos usuários, em especial, questōes relativas à qualidade e presteza no atendimento de suas necessidades e reclamaçóes à correção na cobrança realizada por meio da conta telefônica:

9.2.5. com vistas a inibir o não-atendimento ou $\propto$ atendimento inadequado ao usuário, adote medidas no sentido 
de sancionar com maior rigor as operadoras de teleforia quando as reclamaçōes dos usuários dirigidas ao call center da ANATEL não tenham sido adequadamente atendidas pelas operadoras sem motivo justificado. ${ }^{43}$

Nesse ponto, pode-se questionar a amplitude do controle exercido pelo. TCU. Barroso possivelmente enxergaria no relatório supracitado inconstitucionalidade, consoante se extrai de sua lição: 44

É fora de dúvida, assim, que o Tribunal de Contas não pode avançar sua atividade fiscalizatónia sobre a atividadefirn da agência reguladora, em clara violação ao princípio fundamental da separação dos Poderes.

Logo, näo pode o Tribunal de Contas, por exemplo, questionar decisōes político-administrativas das agências reguladoras, tampouco requisitar planilhas e relatórios expedidos pela agência ou por concessionário, que especifiquem fiscalização e procedimentos adotados na execução contratual Somente lhe cabe informar-se sobre o que possa ser legitimamente objeto de sua apreciação.

Na esfera do Poder Executivo, nāo se vislumbra controle hierárquico, em face da disposição do art. $8^{\circ}, \S 2^{\circ}$, da LGT, e da inexistência de previsão de recurso hierárquico impróprio, mas apenas um controle sobre o atendimento das políticas públicas, que estão no âmbito da competếncia do Governo. Nessa esteira, leciona Ferreira Filho:45

Assim, seus atos, normativos ou não, fogem à revisão pelas autoridades do Executivo, seja o Ministro a cujo departamento o ente estiver vinculado, seja, em última instância, ao Presidente da República.

Entretanto, não é seguro que prevaleça essa interpretaçăo, à vista dos precedentes. Estes săo no sentido de que o

\footnotetext{
${ }^{43}$ Grifo não original.

${ }^{4}$ BARROSO, Op. Cit. p. 130.

${ }^{4}$ FEREEIRA FILHO, Op. Cit., p. 1.40.
} 
chefe do Executivo pode sempre rever atos da administração indireta.

Existe também a fiscalização desempenhada por parte da Controladoria-Geral da União - CGU -, relativa à gestão de patrimônio e de recursos públicos, além de outras funçôes.

Por fim, o organograma da Agência contempla os órgãos de ouvidoria, auditoria e corregedoria que exercem a atividade de controle interno.

\section{Os Atributos de Autonomia e Independência da ANATEL}

Inicialmente, buscou-se identificar na doutrina a delineação do conceito de independência, característica considerada como marca diferencial das agências reguladoras, e de autonomia, deparando-se com um quadro de inexistência de definição precisa do que seria a independência e a autonomia desses entes. Ainda assim, menciona-se algumas notas de consenso em relação à ausência de independểncia absoluta, à constatação de autonomia reforçada e à importância desses atributos.

Faz-se a ressalva que a análise desses atributos dar-se-á de forma conjunta, poís estão intrinsecamente conectados.

Prima facie, destaca-se que a expressão "independência administrativa" da ANATEL já foi atacada na Açảo Direta de Inconstitucionalidade $n .^{\circ} 1.668 / \mathrm{DF}$, que objetivava fulminar diversos dispositivos e expressóes da LGT, uma vez que aquela seria estranha às instituiçōes e às normas de Direito Administrativo decorrentes da Constituição Federal, em síntese, ferindo a competência do Presidente da República de direção superior da Administração Pública, a competência do Ministro pertinente de supervisâo, a impossibilidade de regime especial e o atributo de independência concedido apenas aos três poderes. A ação foi proposta pelos Partidos Comunista do Brasil, dos Trabalhadores, Democrático Trabalhista e 
Socialista Brasileiro. No tocante à referência à independência administrativa da ANATEL contida nos arts. $8^{\circ}, \S 2^{\circ}$, e art. $9^{\circ}$ da LGT, o Tribunal, por votação unânime, não conheceu da ação direta de inconstitucionalidade.

Nos termos do voto do Relator, Ministro Marco Aurélio, a expressão independência administrativa exarada na LGT, não afasta a tutela por parte da própria administração pública federal, nem implica entidade soberana, afastada do controle pertinente, compreendendo-se a independência, como autonomia.

Passa-se a uma análise das idéias doutrinárias sobre o tema. Lehfeld ${ }^{\circ}$ ressalta a importância da independência:

A independência efetiva da ANATEL se reveste de particular importânciá, pois permite que sejam atingidas a credibilidade e a eficiência das políticas regulatórias. $A$ introdução da concorrência e o cumprimento das metas de universalização dos serviços só ocorrerão, de fato, com a presença de uma agência que detenha força e independência suficientes para implementar essas políticas regulatớrias.

Sifontes ${ }^{47}$ identifica $o$ atributo da independência como maior grau de autonomia na tomada de decisões sem a influência do Governo e dos regulados. Veja-se:

Neste sentido, quando falamos de independência, nos referimos ao grau de autonomia que o regulador possui para tomar decisóes isola das do poder político e das firmas reguladas, assumindo que a regulaça de serviços públicos tem como finalidade, proteger os consumidores do abuso das firmas com poder de mercado, proteger os investimentos de oportunismo governamental e promover a eficiência econômica.

\footnotetext{
SEEHFELD, Op. Cit, , p. 96

${ }_{47 S I F O N T E S}$, Domingo. Regulación Económico y Agencias Regulatorias Independientes: una Revision de la Literatura. Enciclopedia y Biblioteca Virtual de las Ciencias Sociales, Económicas y Juridicas Disponlvel en: <htpp/wwweumed.net/ce/ds regulat.htm>. Acesso em $06 / 08 / 2007$. p. 13. Traduçăo livre.
} 
Moraes $^{48}$ fala em independếncia funcional e financeira das ARs, delineada pela autonomia financeira, assegurada pela disponibilidade de recursos humanos, infra-estrutura material e dotaçấo orçamentária; pela possibilidade de escotha dos instrumentos de regulação e pela forma de nomeação de seus dirigentes.

Ja Wald e Moraes ${ }^{49}$ apresentam uma definição diferenciada, focada nos resultados, conforme se percebe do fragmento abaixo:

Tem-se entendido que uma regulação eficiente deve atender a dois requisitos essenciais: $a$ independência da agência reguladora (definida como a capacidade de buscar prioritariamente $o$ atendimento dos direitos e interesses do usuánio e a eficiência da indústria, em detrimento de outros objetivos conflitantes, tais como a maximização do lucro, em sistemas monopolistas, a concentração de empresas em setores mais rentáveis do mercado, ou a maximização das receitas fiscais) e a escolha de instrumentos que incentivem a eficiência produtiva e alocativa.

\section{$[\ldots]$}

São identificadas quatro dimensões que caracterizam uma agência reguladora: a independência decisória, a independência de objetivos, a independência de instrumentos e a independência financeira.

Com propriedade, Aragão ${ }^{50}$ sintetiza as características desse atributo, destacando seu caráter năo absoluto, a sua definição como uma autonomia reforçada e a sua instrumentalização. É de sua dicção:

\footnotetext{
MORAES, Op, Cit , p. 25.26

4WAID, Amoldo MORAES, Luíza Rangel de Agencias Reguladoras Revista de Informaçá Legislativa, a. $36, \mathrm{n}^{\circ} 141$, jan/mar, 1999. Disponível em: <http/f www senado govbr/web/cegraf/ril/Pal/pdf 141/r141-12.pdf>. Acesso em: 08/01/ 2008. p. 145-146.

"5RAGÄO, Op. Cit., p. 9-10.
} 
Entendemos que a independência das agências reguladoras deve ser tratada sem preconceitos ou mitificações de antigas concepções jurídicas que, no mundo atual, são insuficientes ou mesmo ingênuas. Com efeito, limitar as formas de atuaçấo e organização estatal àquelas do século XVIII, ao invés de, como afirmado pelos autores mais tradicionais, proteger a sociedade, retira-lhe a possibilidade de regulamentaçầo efetiva dos seus interesses.

É importante descle já frisar que a qualificaçấo de "independente", comumente atribuída às agências reguladoras, deve ser entendida em termos. Em nenhum país onde foram instituídas possuem independência em sentido próprio, mas apenas maior ou menos autonomia, dentro dos parâmetros fixados pelo ordenamento jurídico. Em outras palavras, o termo "independência" utilizado não é, logicamente, equivalente a "soberania", mas sim a uma efetiva descentralização autônoma, a uma autonomia "reforçada" em comparação com a autonomia das demais entidades da Administraçăo Indireta, o que, como será delimitado ao longo do trabalho, não exclui a coordenação pela Administração central.

Neste sentido, as principais notas da autonomia/independência das agências reguladoras são a impossibilidade de exoneraçáo ad nutum dos seus dirigentes, a organização colegiada, a formação técnica, competências regulatórias e a impossibilidade de recursos hierárquicos ímpróprios; sendo que apenas a conjunção destes elementos resultará na conceituaçăo de uma entidade como agência reguladora independente.

Mendes ${ }^{51}$ apresenta esse atributo como a impossibilidade de ingerência do Governo na atividade da Agência: “Tem como caracteristica fundamental independência em relação do poder político, [...], podendo realizar as atividades de regulaçâo (fiscalização, produção de normas, solução de conflitos etc.) sem qualquer ingerência do núcleo do Poder Executivo".

"MENDES, Op. Cit., p. 135.

Cadernos do PPG em Direito UFRGS, Porto Alegre, $v, 6, n .7$ e 8, p. 151-193, 2007. 
Neto $^{52}$ aborda o tema como uma característica inerente à garantia do exercício politicamente neutro da regulação, devendo ser entendida com um "conteúdo restrito a quatro aspectos: $a$ independência dos gestores, a técnica, a normativa e a gerencial, orçamentária e financeira".

Moreira e Maças $^{53}$ ensinam que a regulaçäo por autoridade independente supöe sempre uma separação entre a esfera da política econômica, que cabe ao Governo, e a esfera da regulaçâo em sentido estrito, que pode e, em certos casos, deve ser desgovernamentalizada". No tocante à independência, advertem o afastamento do jogo político governamental, consoante o fragmento que ora se colaciona:

O que distingue a regulaçāo independente é o facto de ela ter passado a ficar fora da orbita governamental, dentro da qual tradicionalmente se inseriam todas as funções administrativas e de execução das leis em geral. Desse modo, o panorama da regulação alterou-se substancialmente, sobretudo quanto ao seu formato institucional e quanto à relação com o Governo. ${ }^{\text {5. }}$

Os autores compreendem a independência em sentido orgânico (estrutural) - "composição, modo de designaçāo dos titulares dos seus órgãos, regras relativas ao mandato e regime de incompatibilidades", ${ }^{55}$ que, em síntese, reflete a impossibilidade de destituição dos seus dirigentes pelo Governo antes do término dos seus mandatos; em sentido funcional (quanto à atividade) - independência decisória - aúsência de subordinação a controle hierárquico ou tutelar do Poder Executivo; e em relaçäo aos interesses setoriais que integram o grupo ou grupos que desempenham a atividade regulada ${ }^{56}$ Eles concluem no seguinte sentido: ${ }^{57}$

\footnotetext{
${ }^{52}$ NETO, Diogo de Figueiredo Moreira. Direito Regulatório. Rib de Janeiro: Renovar, 2003. p. 165-166.

5.3 MOREIRA, Vital; MACAS, Fernanda, Op. Cit. p. 13.

5 SA MOREIRA, Vital; MACAS, Femanda, Op. Cit, p. 15.

\$MOREIRA, Vital; MACAS, Femanda, Op. Cit.s, p. 25.

${ }^{5 t}$ MOREIRA, Vital; MAÇAS, Fernanda, Op. Cit. p. $24-27$.

5 MOREIRA, Vital; MACAS, Fernanda, Op. Cit., p. 28.
} 
Em jeito de síntese, podemos dizer que o conceito de independência assume aqui um significado preciso, essencialmente negativo, qual seja o corte com o aparelho executivo a ausência de sujeiçâo à autoridade ou orientação de qualquer outra entidade política ou administrativa.

Além disso, é interessante notar que os autores portugueses enxergam nas agências reguladoras uma entidade ${ }^{58}$ que transcende da administração, apresentando-se como perseguidora dos interesses de representante do Estado. Veja-se:

[...] a verdade é que as AAI não integram a administração descentralizada, uma vez que em termos substantivos elas não prosseguem interesses próprios ou de colectividades auto-administradas, mas sim interesses do Estado.

Marques Neto, ao estudar o assunto divide independência em orgânica e administrativa. $\mathrm{Na}$ sua classificação, a primeira diz respeito aos mecanismos que asseguram a neutralidade da agência em relação "à vontade política do poder central para além das metas, objetivos e princípios constantes das políticas públicas estabelecidas para o setor" ${ }^{59}$ Concretiza-se nos seguintes instrumentos: estabilidade dos dirigentes (mandato por prazo determinado e inamovibilidade) e ausência de controle hierárquico (inexistência de recurso hierárquico impróprio). Já a independência administrativa, visa possibilitar o exercício e uma regulação independente. Seus mecanismos são: autonomia de gestão (organizar e gerir seu orçamento) autonomia financeira (garantia de recursos financeiros não dependente da vontade da gestão do tesouro); liberdade para organizar seus serviços (auto-organizaçắo) e regime de pessoal compatível.

$\mathrm{O}$ autor ainda coloca importantes questöes ao abordar as autonomias de gestão e de finanças, cujas relevantes indagações transcreve-se abaixo:

\footnotetext{
58. MOREIRA, Vital MAÇAS, Femanda, Op. Cit, p. 31.

${ }^{9}$ MARQUES NETO, Agências Reguladoras Independentes, p. 72-78.
} 
Tal autonomia, no nosso entender; interdita contingenciamentos ou cortes orçamentários que sejam feitos para atender a objetivos de política monetária ou fiscal. Ela também torna absolutamente incompatível com as agências reguladoras a previsão de contratos de gestão [...].

Quando as receitas das agências provierem da cobrança das taxas, é importante dizer, os recursos auferidos deverão ser necessariamente despendidos no exercício da atividade regulatória. ${ }^{60}$

Para finalizar as idéias do autor, faz-se necessário transladar uma fração que descreve com propriedade como a atuação do órgão regulador deve pautar-se em relaçăo aos interesses envolvidos na atividade de regulação. ${ }^{\text {1 }}$

A independência se póe, portanto, essencial para que o regulador possa exercer suas funções de forma eqüidistante em relação aos interesses dos regulados (operadores econômicos), dos beneficiários da regulaçăo (os usuários, consumidores, cidadãos) e ainda do próprio poder político, ficando protegido tanto dos interesses governamentais de ocasiäo, quanto dos interesses estatais diretamente relacionados ao setor regulado (como titular da atividade objeto de regulaçăo - no caso de serviços públicos -; como titular de bem explorado no setor - no caso de bens públicos escassos ou de bens reversíveis -; e no caso de titular de capital de empresa que opera no setor regulado - nas situações em que o setor foi aberto à competição, mas eles remanesceram operadores públicos).

Procedendo-se na análise ainda dos atributos de autonomia e independência, faz-se necessário mencionar o precedente Humphrey s Executor versus Unites States, decidido em 27 de maío de 1935, pela Suprema Corte Norte-Americana. Em resumo, William E. Humphrey foi nomeado pelo então Presidente Hoover como membro da Comissão Federal de

\footnotetext{
MAFQUES NETO, Agencias Reguladoras Independentes, p. 76.-77.

- MAKQUES NETO, Agencias Reguladoras Independentes; p. 68.
} 
Comércio, em 10 de dezembro de 1931, e confirmado pelo Senado do Estados Unidos, para um mandato de 7 anos. No dia 25 de julho de 1933, o Presidente Roosevelt solicitou a sua renúncia. Após resposta negativa, o Presidente o demitiu em 7 de outubro de 1933. A Suprema Corte decidiu pela constitucionalidade de mandatos com prazo determinado e sem possibilidade de demissão ad nutum para determinadas autoridades, visto que o Congresso, no exercício de seu podèr, criou agências com poderes quase-judiciais e quaselegislativos. ${ }^{62}$

O Supremo Tribunal Federal já foi instado a se manifestar sobre a restrição imposta à possibilidade de demissão dos dirigentes das agências reguladoras na Medida Cautelar na Ação Direta de Inconstitucionalidade n. ${ }^{\circ} 1949 / \mathrm{RS}^{63}$ proposta pelo Governador do Estado do Rio Grande do Sul, na qual, em síntese, questionou-se a constitucionalidade da necessidade de aprovação pela Assembléia Estadual da nomeação

\footnotetext{
"traduça lve Trecho onginal do precedente: "We think it plain under the Constitution that illimitable power of removal is not possessed by the President in respect of officers of the chacacter of those just named. The authority of Congress, in creating quasilegislative or quasi-judicial agencies, to require them to act in discharge of their duties independently of executive control cannot well be doubted, and that authority includes, as an appropriate incident, power to fix the period during which they shall continue in office, and to forbid their removal except for cause in the meantime. For it is quite evident that one who holds his office only during the pleasure of another cannot be depended upon to maintain an attitude of independence against the latter's will."

G Veja-se o brilhante Voto Vista do Ministro Nelson Jobim, que constitul verdadeira aula de direito comparado sobre o tema, destacando se o resgate do voto visionávio do Ministo Victor Leal, no MS n ${ }^{\circ}$ 8.693, de 17.11.1962 (RTJ 25/55), que aquí se transcreve trechos: "[..] eis uma providência que se integra, com toda a naturalidade, no regime de autonomia administrativa atribuido, por lei, a certos órgáos. Vísa a investidura de prazo certo a garantir a continuldade de orientaçao e ndependericia de açăo de tais entidades autônomas, de modo que os tituares, assim protegidos contra as injunçôes do momento, possam dar plena execução à política adotada pelo. Poder Legislativo, ao instituir o órgăo autônomo, e definir-the as atribuiçöes [....]". "O cargo que a lei dotou com a investidura de prazo certo não pode ser tido como função de confiança, porque é justamente o oposto dela, sendo antinômicos os propósitos do legislador num e noutro caso. Permitam me repetir um trecho da decisão da Corte Suprema, no caso Humphrey, repetida no Caso Wiener: 'quem exerce o cargo somente enquanto agrada o outro, não pode, por isso mesmo, manter uma atítude de independência ante vontade desse outro."
} 
dos membros do Conselho Superior da Agência Estadual de Regulação dos Serviços Públicos Delegados do Rio Grande do Sul - AGERGS -, bem como a possibilidade de destituição dos mesmos apenas por decisão daquele Parlamento. A decisảo afirma a constitucionalidade da subordinaçẫo da nomeação de dirigentes de autarquias à prévia aprovação do Parlamento, ressaltando no seu item 4 que " $A$ investidura a termo - nâo impugnada e plenamente compativel com a natureza das funçōes das agências reguladoras - $\varepsilon$, porém, incompatível com a demissão ad nutum pelo Poder Executivo [...]". ${ }^{64}$

Aragăo explica dualidade entre a autonomia dessas entidades e a Administração Pública: ${ }^{65}$

Não há, portanto, antagonismo entre a autonomia de entidades e órgãos materialmente descentralizados com a unidade da Administração, muito pelo contrário: a Administraçāo Pública contemporânea, para cumprir as suas funções e atender aos valores e princípios constitucionais a ela impostos, deve atuar, ao mesmo tempo, coordenada e descentralizadamente.

Vemo-nos diante de um Direito Administrativo mais complexo e plural, que abandona a idéia de que uma arividade administrativa só é racional na medida em que estiver previamente prevista, detalhadamente normatizada esujeita a uma linha hierárquica;, que substitui por técnicas de análise, gestāo e responsabilidades estratégicas.

O autor ainda vincula a independência aos valores tutelados por estas entidades, cuja defesa desses bens fundamenta uma atuação neutra e com liberdade decisória, consoante o texto abaixo colacionado: ${ }^{67}$

A independência assegurada aos órgãos e entidades neutrais do Estado é uma relação qualificada com os bens

\footnotetext{
64 Item constante da ementa do acórdäo exarado na ADI-MC ñ 1949/RS.

ARAGAO, Op. Cit. p. 21 .

${ }^{\circ}$ Grifo original.

"ARAGAO, Op. Cit. p. 445.
} 
e valores que tutelam ou expressam, que os separa de tudo o que não for a eles concernente. $\mathrm{Na}$ independência, portanto, estão ínsitos traços de sujeição a estes bens valores, quem se agregam à autoridade neutral, podendo-se dizer haver "uma relação de 'fundamentação', ou uma relação hierărquica imprópria, entre os valores tutelados e os órgãos neutrais, relação que produz a liberdade dos órgãos para atuar na proteção destes valores, o que lhes dá autoridade porque demonsira que os órgãos independentes pertencem ao ordenamento no qual, justamente com os valores tutelados, estão inseridos".

Em que pese a inexistência de consenso sobre o significado da atribuição de independência a essas autarquias especiais, especialmente em face da formatação jurídicoinstitucional da Administração Pública no país, pode ser elaborada uma síntese, congregando os elementos comuns encontrados na doutrina. Dessa forma, menciona-se, primeiramente, que a independência administrativa estabelecida pelo legislador para a ANATEL no $\$ 2^{\circ}$ do art. $8^{\circ}$ da Lei $n .{ }^{\circ}$ $9.472 / 97$, que também preceitua que a Agência como "autoridade administrativa independente ${ }^{*}$, deve coadunar-se com a ordenamento vigente, importando em inexistência de independência absoluta, pois apenas a República Federativa do Brasil é soberana, inclusive os três poderes sofrem limitações em sua independência, por meio do sistema de freios e contrapesos.

Ademais, a agência foi instituída como autarquia, com características especiais, que é definida pelo art. $5^{\circ}, 11$, do Decreto-lei $n .200$, de 25 de fevereiro de 1967 , como "o serviço autônomo, criado por lei com personalidade jurídica, patrimônio e receita para executar atividades típicas da Administração Pública, que requeiram, para seu melhor funcionamento, gestão administrativa e financeira descentralizada".

Mello ${ }^{9}$ leciona:

\footnotetext{
68. Art. $9^{\circ}$ da Lein. ${ }^{\circ} 9.472 / 97$.

GMELLO Celso Antônio Bandeira de Curso de Direito Administrativo. 14 ed. São Paulo: Malheiros, 2002. 936 p. p. $148-149$.
} 
Sendo, como são, pessoas jurídicas, as autarquias gozam de liberdade administrativa nos limites da lei que as criou: não são subordinadas a órgão algum do Estado, mas apenas controladas, como ao diante melhor se esclarece. Constituindo-se em centros subjetivados de direitos e obrigaçôes distintos do Estado, seus assuntos são assuntos próprios; seus negócios, negócios próprios; seus recursos, não importa se oriundos de trespasse estatal ou hauridos como produto da atividade que lhes seja afeta, configuram recursos e patrimônios próprios, de tal sorte que desfrutam de "autonomia" financeira, tanto como administrativa; ou seja, suas gestões administrativa e financeira necessariamente são de suas próprias alçadas - logo, descentralizadas.

\section{$[\ldots]$}

O controle - $O$ controle das autarquias, às vezes designado, sobretudo na doutrina estrangeira como tutela, é o poder que assiste à Administração Central de influir sobre elás com o propósito de conformá-las ao cumprimento dos objetivos públicos em vista dos quais foram criadas, harmonizando-as com a atuação administrativa global do Estado.

Ora, o controle do Poder Executivo é exercido mediante o cumprimento das políticas publicas setoriais, näo se podendo falar em usurpação das competências do Ministério ao qual a agência está vinculada e do Presidente como chefe da administração pública, fulcro art. 84, II, da Carta Política, cujo controle será desempenhado nos termos anteriomente citados. Embora a LGA tenha revogado a possibilidade de demissão, em face do năo cumprimento das políticas públicas estabelecidas, contida no art. $26, \S 1^{\circ}$, da LGT, ela autoriza a perda decorrente de Processo Administrativo Disciplinar, o qual serve para apurar infrações praticadas por servidor, nos termos do art. 148, caput, da Lei $n^{\circ}{ }^{\circ} 8.112$, de 11 de dezembro de 1990, podendo este descumprimento ser enquadrado como violação aos deveres de servidor constantes do art. 116 desta lei $e$, eventualmente, como na proibição contemplada no 
seu art. 117, inciso IV, que veda a resistência injustificada ao andamento de documento e processo ou execução de serviço.

Portanto, como entidade autárquica, já detém autonomia administrativa, financeira e de gestão, acrescendo-se, conforme disposto no $\$ 2^{\circ}$ do art. $8^{\circ}$, independência administrativa, ausência de subordinação hierárquica, estabilidade e mandato fixo de seus dirigentes. Note-se que essas características recebem nomenclatura diferenciada pelos doutrinadores, mas as conclusōes são próximas. Nesse sentido, pode-se inferir que a independência é reconhecida principalmente nos instrumentos de mandato fixo e não-coincidente de seus diretores, na sua impossibilidade de sua demissão ad nutum e na ausência de recurso hierárquico impróprio, a fim de possibilitar que a autoridade possa exercer suas atribuições de forma equidistante dos interesses das empresas reguladas, do Governo e da sociedade, na tentativa de esquivar-se das vicissitudes do jogo político-partidário e dos grandes interesses econômicos envolvidos no setor.

Ao mesmo tempo em que atribuir independência visa a uma atuação técnica da entidade, no intuito de que os interesses do Estado prevaleçam sobre aqueles do governo, das empresas e das corporações reguladas e dos consumidores, os quais devem ser sopesados e coordenados dentro do projeto de país e de sociedade estabelecido pelo legislador, o afastamento do Poder Político pode gerar vulnerabilidade do regulador, propiciando o fenômeno da captura, que ocorre "quando o agente regulado, pelo poder económico que possui, passa a determinar o comportamento do ente regulador" $7^{70}$

Marques Neto ${ }^{7}$ compendia a importância da independência e dos instrumentos que a materializam:

\footnotetext{
${ }^{7}$ Definiça de MENDES, Conrad Hübner. Refoma do Fstado e Agências Reguladoras: Estatelecendo os Parâmetros de Discussäo. In: SUNDFELD, Carlos Ari (Coord.). Diretto Administrativo Econốmico. I ed. 2 tor Săo Paulo: Malheiros, 2002. 405 p. 98-138. p. 105. ${ }^{7}$ MARQUES NETO, Floriano Azevedo. A Nova Regulaço Estatal e as Agências Independentes. In: SUNDFELD, Carlos Ari (Coord.). Direito Administrativo Econamimion. 1 ed. 2 tir. Săo Paulo: Malheiros, 2002. 405 p.72-98. p. 87-88.
} 
Parece-nos absolutamente relevante que a atividade do órgão regulador se desenvolva com independência frente às vicissitudes do poder político. Bem é verdade que será no âmbito governamental (envolvendo Executivo e Legislativo) que serão definidas as pautas, as balizas, da atividade regulatória: ou seja, tanto as leis, que ancilam os instrumentos regulatórios como mesmo as macropolíticas para o setor. Porém, definidos estes marcos, devem as agências desenvolver sua atividade com um grau elevado de independência em face do poder político, sob pena de se converterem em mera longa manus do nucleo estrategico estatal. A especificidade especialidade, que predicam a necessidade de um setor contar com um órgão regu-

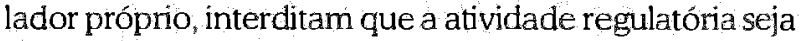
permanentemente pautada pela interferência política. A nova regulação é, sem dúvida, um instrumento de implementação de uma política pública em determinado setor. Não pode, porém, se transformar em instrumento do jogo político em particular.

[...]

Em suma, a independència das agências as torna menos atreladas ao curso do devir político, em especial das variáveis eleitorais, muito mais dependentes da permanente comunicaçăo, balizada por objetivos previamente definidos, com o setor específico objeto da sua atividade regulatória. Ela se concretizará mediante alguns instrumentos essenciais: i) a estabilidade dos dirigentes; ii) a autonomia de gestão do órgão; iii) o estabelecimento de fontes próprias de recursos para o órgão, se possivel geradas dó próprio exerćício da atividade regulatôria; iv) a não-vinculaçăo hierárquica a qualquer instância de governo; v) a inexistência de instância revisora hierárquica dos seus atos, ressalvada a revisão judicial.

Assim, pode-se dizer que além da autonomia própria das entidades autárquicas que compōem a administração direta, as agências reguladoras possuem independência em relaçâo a outros interesses, especialmente dos atores do jogo-político 
partidário e dos grupos econômicos atingidos pela regulação, que se concretiza no mandato fixo e não-coincidente de seus dirigentes, na impossibilidade de demissão ad nutum dos mesmos, na existência da quarentena e na inexistência de recurso hierárquico impróprio.

\section{Conclusão}

O presente trabalho procurou discutir alguns aspectos relevantes no tocante à independência e à autonomia da ANATEL. Para tanto, partiu-se de uma sintese sobre a transformação da figura estatal interventora da ordem econômica, cujo papel de atuação sofreu substancial reforma no final da década de 1990 no Brasil. Até então, tinha-se o Estado Empresário que explorava muitos setores da atividade econômica, especialmente, os relacionados à prestação de serviços públi$\cos$ o qual se configura atualmente em um Estado Regulador, agindo indiretamente na economia, no sentido de regular, fiscalizar, planejar, incentivar, conduzir e orientar as atividades para o alcance dos fins estabelecidos pela Constituição e pelo legislador, os últimos consubstanciados nas políticas públicas.

Procurou-se ressaltar que essa remodelação do Estado não implica a sua ausência da ordem econômica, nem o abandono do Estado do Bem-Estar Social. Busca-se justamente mais eficiência na concretização do projeto de país institucionalizado na Constituição de 1988. Posteriormente, passou se ao estudo das Agências Reguladoras notadamente da ANATEL, explicitando suas características, estrutura, atribuiçōes, gestão e peculiaridades, a fim de subsidiar o estudo dos seus aíributos de independência e autonomia.

Pode-se dizer que além da autonomia própria das entidades autárquicas que compôe a administração indireta, as agências reguladoras possuem independência em relação a outros interesses, especialmente aos dos atores do jogo-politico partidário e aos dos grupos económicos atingidos pela 
regulação, concretizando-se no mandato fixo e não-coincidente de seus dirigentes, na impossibilidade de demissão ad nutum dos mesmos, na existência da quarentena e na inexistência de recurso hierárquico impróprio.

A atribuição de independência objetiva uma atuação técnica da entidade, a fim de que os interesses do Estado prevaleçam sobre aqueles do govemo, das empresas e corporaçōes reguladas e, até mesmo, dos consumidores, os quais devem ser sopesados e coordenados dentro do projeto de país e de sociedade estabelecido nossa Carta Política.

\section{Referências}

SILVA, José Afonso da. Curso de Direito Constitucional Positivo. 19 ed São Paulo: Malheiros, 2001.878 p.

AGUILLAR, Femando Herren. Controle Social de Serviços Püblicos. SãoPaulo: Editora Max Limonad, 1999. 302p.

ANATEL. Curso de Formaçắo para os Candidatos ao Cargo de Especialista em Regulaçấo de Serviços Públicos de Telecomunicaçóes. Módulo V Defesa da Concorrência em Telecomunicaçoes. Instrutores: Carlos Jacques Gomes, Daniela Arbex e Miguel Mattos. Brasilia: CESPE, 2005.67p.

Curso de Formação para os Candidatos ao Cargo de Especialista em Regulação de Serviços Públicos de Telecomunicaçôes. Módulo V: Defesa da Concorrência em Telecomunicaçôes. Instrutor Tarćsio Barroso da Graça. Brasilia: CESPE, 2005. 46p.

Relatónos Disponível em: <http://www anatel.gov.br/Portal/ exibirPortallnternet.do >. Acesso em: 25/05/2008.

ARAGÄO, Alexandre Santos de Agéncias Reguladoras e a Euolução do Direitó Administrativo Econômico. 2 ed. 2 tir. Rio de Janeiro: Forense, 2004. 509 p.

ARANHA, Márcio lorio (Org.). Direito das Telecomunicaçoes: Estrutura Institucional Regulatốria e Infra-estrutura das Telecomunicaçōes no Brasil. Brasilia: JR Gráfica, 2005.

ASSOCIACÃO BRASILEIRA DE AGENNCLAS REGULADORAS - ABAR Agên clas Reguladoras. Porto Alegre: ABAR, 2003. Disponivel em: <http// wwwabarorg.br/legba/bancoDeMidia/arquivos/agencias reguladoras pdf $>$. Acesso em: 08/01/2008.

BINENBOJM, Gustavo. Agencias Reguladoras Independentes e Democracia no Brasil. Revista Eletrônica de Direito Administrativo Econômico, Salvador, IDPB, 
n.3, ago/out de 2005. Disponível na Intemet: <http://www direitodo estado.com.br/>. Acesso em: 17/07/2006.

BOBBIO, Norberto; MATTEUCCI, Nicola; PASQUINO, Gianfranco. Dicionário de politica. trad. Varrialle, Carmen C. 12. ed. Brasília: Ed. da Unb, 2004. 2 v. 1330 p.

BONAVIDES, Paulo. Curso de Direito Constitucional. 9 ed São Paulo: Malheiros Editores, 2000. 793p.

BRASIL. TRIBUNAL DE CONTAS DA UNIÂO O Controle Extemo das Agências Reguladoras: questôes relevantes sobre o setor elétrico e de petróleo e gás natural. Brasilia: TCU, SEFID, 2003. 28p. Disponível em: <http:/ www2.tcu. gov.br/portal/page? pageid $=33,4564798$ dad $=$ portal6 schema-PORTAL> Acesso em: 17/10/2007.

CADERNOS ADENAUER II (2001), n. 3 . Burocracia e Reforma do Estado, Sâo Paulo: Fundaçấo Konrad Adenauer, jul. 2001. 109 p.

CÂMARA AMERICANA DE COMÉRCIO PARA O BRASIL - AMCHAM. Relatónio da Agência Nacional de Telecomunicaçōes - ANATEL. 2007. Disponível no sítio <http:/www.amcham.com.br/update/2007/update2007-10-19a dtml.pdf> Acesso em: 25/05/2008.72 p.

DI PIETRO, Maria Sylvia Zanella. Parcerias na Administraçäo Pública: Concessão, Permissão, Franquia, Terceirização, Parceria Público-Privada e Outras Formas. 5 ed. Săo Paulo: Atlas, 2005. 449.p.

FARIA, José Eduardo C. O. O direito na economia globalizada. São Paulo: Malheiros, 1999. $359 \mathrm{p}$.

. (Org.). Regulação, direito e democracia. São Paulo: Fundaçẵo Perseu Abramo, 2002. $104 \mathrm{p}$.

FERRAZ JUNIOR, Tércio Sampaio Agências Reguladoras: Legalidade e Constitucionalidade. 21 p. Disponível na Internet: <http $/ /$ www.bresserpereira. org.br/ Document 2008.

GRAU, Eros Roberto. A Ordem Econômica na Constituiçāo de 1988. 9ed. rev. e . atual. São Paulo: Malheiros, 2004. 351 p.

GROTTI, Dinorá Adelaide Musetti. As Agências Reguladoras. Revista Eletrônica de Direito Administrativo Econômico, Salvador, IDPB, n.6, mai/jun/jul de 2006. Disponivel na Intemet: <http:/www.direitodoestado.com.br/> Acesso em: $17 / 06 / 2006$.

Serviço público e a Constituição brasileira de 1988. São Paulo: Malheiros, 2003. 406p.

HERRERA, Alejandra. Introdução ao Estudo da Lei Geral de Telecomunicaçōes do Brasil. Săo Paulo: Editora Singular, 2001. 255p. 
LEHFELD, Lucas de Souza. As novas tendências na regulamentação do sistema de telecomunicações pela Agência Nacional de Telecomunicaçôes (ANATEL). Rio de Janeiro: Renovar, 2003. 232 p.

MARQUES NETO, Floniano Peixoto de Azevedo. Agências reguladoras: instrumentos do fortalecimento do Estado. Porto Alegre: ABAR, 2000.

Balanço 'e Perspectivas das Agências Reguladoras no Brasil Revista Eletrônica sobre a Reforma do Estado, Salvador, Instituto de Direito Público da Bahia, $n$. 1, março, 2005. Disponível na Intemet: <http//www direitodo estado.com/>. Acesso em: 15/07/2006.

Agências Reguladoras Independentes - Fundamentos e seu Regime Jurídico. Belo Horizonte: Editora Fórum, 2005. 220 p.

MATTOS, Paulo Todescan Lessa. A Formação do Estado Regulador. NOVOS ESTUDOS, CEBRAP, n. 76, novembro 2006, pp. 139-156, Disponível em: $<$ http://www.scielo.br/pdf/nec/n76/07.pdf> . Acesso em: 13/08/2007.

MELLO, Celso Antônịo Bandeira de. Curso de Direito Administrativo. 14 ed. São Paulo: Malheiros, 2002.

MORAES, Alexandre de. Direito Constitucional São Paulo: Atlas; 2004. 15 ed. 863p.

(Org) Agências Reguladoras. São Paulo: Atlas, 2002. 170 p.

MOREIRA, Vital; MAÇAS, Fernanda. Autoridades Reguladoras Independentes: Estudo e Projecto de Lei-Quadro. Coimbra: Coimbra Editora, 2003. 318p.

NETO, Diogo de Figueiredo Moreira. Direito Regulatório. Rio de Janeiro: Renovar, 2003.

. Apontamentos sobre a Reforma Administrativa. Rio de Janeiro: Renovar, 1999. 182p.

ORGANIZAÇĀO PARA A COOPERAÇĀO EESENVOLVIMENTOECONÔMICO-OCDE Relatório sobre a Reforma Regulatoria-Brasil: fortalecendo a governança para o crescimiento. Disponivel em: <http:/www. planejamento. gov.br/gestao/conteudo/noticias/znoticialasp?Cod $=2415>$. Acesso em: $05 /$ 06/2008. 352p.

SIFONTES, Domingo. Regulación Económica y Agencias Regulatorias Independientes: una Revisión de la Literatura. Enciclopedia y Biblioteca Virtual de las Ciencias Sociales, Económicas y Jurídicas. Disponível em: < http:/ www.eumed net/ce/ds-regulat htm > Acesso em 06/08/2007.

SUNDFELD, Carlos Ari (Coord.). Direito Administrativo Econômico. 1 ed. 2 tirSăo Paulo: Malheiros, 2002. 405 P.

WALD, Amoldo; MORAES, Luíza Rangel de. Agências Reguladoras. Revista de Informação Legislativa, a. 36, n. 14a1, jan/mar, 1999. Disponivel em: <http'/ 
/wwwsenado.gov.br/web/cegraf/ril/Pdf/pdf 141/r141-12.pdf $>$. Acesco em 08 $01 / 2008$.

ZIMMER JÛNIOR, Aloísio. Direito Administrativo. Porto Alegre: Verbo, 2007. $432 \mathrm{p}$. 